\title{
The structure and thermal behaviour of sodium and potassium multinuclear compounds with hexamethylenetetramine
}

\author{
Ewelina Czubacka • Rafal Kruszynski • \\ Tomasz Sieranski
}

Received: 27 July 2011/Accepted: 21 September 2011 / Published online: 11 October 2011

(C) The Author(s) 2011. This article is published with open access at Springerlink.com

\begin{abstract}
Sodium and potassium thiocyanate complex compounds of formulae $\left[\mathrm{Na}(\mathrm{hmta})\left(\mathrm{H}_{2} \mathrm{O}\right)_{4}\right]_{2}^{2+} \cdot 2 \mathrm{SCN}^{-}$(1) and $\left[\mathrm{K}_{2}(\mathrm{hmta})(\mathrm{SCN})_{2}\right]_{n}$ (2) have been synthesized and characterised by IR spectroscopy, thermogravimetry coupled with differential thermal analysis, elemental analysis and X-ray crystallography. Each sodium and potassium cation is six co-ordinated, the sodium by one monofunctional hmta molecule, three terminal water molecules and two bridging water molecules, and the potassium by two bridging tetrafunctional hmta molecules and four bridging tetrafunctional thiocyanate ions. The coordination polyhedra of the central atoms can be described as distorted tetragonal bipyramids. The complex cations and anions of (1) are interconnected by multiple intramolecular $\mathrm{O}($ water $)-\mathrm{H} \cdots \mathrm{N}(\mathrm{hmta} / \mathrm{NCS})$ and $\mathrm{O}($ water $)-\mathrm{H} \cdots \mathrm{S}$ hydrogen bonds to the three dimensional net. In each complex cation the intramolecular $\mathrm{O}-\mathrm{H} \cdots \mathrm{O}$ hydrogen bonds link two terminal water molecules bonded to two metal cations. The compound (2) forms the three dimensional hybrid network in which the classical two-dimensional coordination polymers are linked by inorganic $\mathrm{SCN}^{-}$spacers to the third-dimension. Thermal analyses show that the compounds decompose gradually in three (for 1 ) and two (for 2) steps with formation of $\mathrm{Na}_{2} \mathrm{SO}_{4}$ and $\mathrm{K}_{2} \mathrm{~S}$ as the final products, respectively, for 1 and 2 .
\end{abstract}

Electronic supplementary material The online version of this article (doi:10.1007/s11224-011-9888-7) contains supplementary material, which is available to authorized users.

E. Czubacka · R. Kruszynski $(\bowtie) \cdot$ T. Sieranski

Institute of General and Ecological Chemistry, Technical University of Lodz, Zeromskiego 116, 90-924 Lodz, Poland

e-mail: rafal.kruszynski@p.lodz.pl
Keywords Sodium - Potassium - Thiocyanate . Structure $\cdot$ Hexamethylenetetramine

\section{Introduction}

Nowadays, an increasing interest is put on construction of dinuclear, multinuclear and polymeric coordination compounds [1-4] created by self-assembly [5] of the components (including metal salts and their complexes) [6-9]. Solid materials containing coordination moieties are interesting due to variety of created framework topologies [10, 11], optical [12], catalytic [13, 14], electric [12] and magnetic $[13,15]$ properties. Recently, significant progress has been achieved in orientation and dominant assembly of building blocks into structures with particular topologies and functions, including a selective guest inclusion [1618], ion/molecular recognition [19] or an ion exchange [20, 21]. The di- and more multinuclear coordination species possessing available multidentate functions are used as spacers for construction of multidimensional compounds or for synthesis of starting materials used to production of shape and size designed nanoparticles.

Hexamethylenetetramine (hmta) is a tetrafunctional neutral organic ligand which can be utilized as an outer coordination sphere modulator of an inner coordination sphere [22] or as a building block of di- and multinuclear compounds (as a crosslinking agent [23]). It has been used to assemble new supramolecular structures with metal ions, via various coordination modes, involving one to four $\mathrm{N}$ atoms of hmta molecule [24-28]. Among the inorganic anions serving as ligands the most popular is ambidentate $\mathrm{SCN}^{-}[29,30]$ due to its great tendency to link metal ions [31]. In addition the antagonism between the different ligands (neutral and ionic) and solvent molecules in 
building into coordination spheres is fundamental, but not fully explained fact. Thus, the coordination behaviour of hmta and $\mathrm{SCN}^{-}$ions towards the $\mathrm{Na}^{+}$and $\mathrm{K}^{+}$cations in aqueous environment was studied to explain interplaying between ligands, solvent water molecules and sodium/ potassium cation as well as check the possibility of utilizing these ligands to create multinuclear sodium/potassium complex compounds.

\section{Experimental}

Materials and synthesis

All chemicals (analytical grade) were obtained from POCh S.A. and used without further purification. The complex compounds $\left[\mathrm{Na}(\mathrm{hmta})\left(\mathrm{H}_{2} \mathrm{O}\right)_{4}\right]_{2}^{2+} \cdot 2 \mathrm{SCN}^{-}$(1) and $\left[\mathrm{K}_{2}(\mathrm{hmta})\right.$ $\left.(\mathrm{SCN})_{2}\right]_{n}(\mathbf{2})$ were obtained in a direct reaction between the salt and the ligand. The sodium and potassium thiocyanates
(0.1170 and $0.0970 \mathrm{~g}$, respectively, for 1 and 2) were dissolved in possible smallest amount of water $\left(4 \mathrm{~cm}^{3}\right)$ and then they were mixed with aqueous solutions of hexamethylenetetramine (molar ratio 1:1). The mixtures were stirred vigorously for 0.5 and $3 \mathrm{~h}$ on a magnetic stirrer, respectively, for 1 and 2, placed in a refrigerator and left to crystallize at about $5{ }^{\circ} \mathrm{C}$. After 6 and 12 weeks (respectively, for 1 and 2) the crystals grown. The products were filtered off and dried in air.

\section{X-ray crystallography}

Colourless rectangular prism shape crystals were mounted in turn on a KM-4-CCD automatic diffractometer equipped with CCD detector, and used for data collection. X-ray intensity data were collected with graphite monochromated $\mathrm{MoK}_{\alpha}$ radiation $(\lambda=0.71073 \AA)$ and $\mathrm{CuK \alpha}(\lambda=$ $1.54178 \AA$ ), respectively, for $\mathbf{1}$ and $\mathbf{2}$, at temperature of 291.0(3) K, with $\omega$ scan mode. The $33 \mathrm{~s}$ exposure times

Table 1 Crystal data and structure refinement details for studied compound

\begin{tabular}{|c|c|c|}
\hline Compound & 1 & 2 \\
\hline Empirical formula & $\mathrm{C}_{14} \mathrm{H}_{40} \mathrm{~N}_{10} \mathrm{Na}_{2} \mathrm{O}_{8} \mathrm{~S}_{2}$ & {$\left[\mathrm{C}_{8} \mathrm{H}_{12} \mathrm{~K}_{2} \mathrm{~N}_{6} \mathrm{~S}_{2}\right]_{\mathrm{n}}$} \\
\hline Formula weight & 586.66 & 334.56 \\
\hline Crystal system, space group & Monoclinic, $P 2_{1} / n$ (No. 14) & Monoclinic, $C 2 / c$ (No. 15) \\
\hline Temperature (K) & $291.0(3)$ & $291.0(3)$ \\
\hline Wavelength & $\lambda(\operatorname{MoK} \alpha)=0.71073$ & $\lambda(\mathrm{CuK \alpha})=1.54178$ \\
\hline \multirow[t]{6}{*}{ Unit cell dimensions $\left(\AA{ }^{\circ}\right)$} & $\mathrm{a}=9.0669(3)$ & $\mathrm{a}=9.2751(8)$ \\
\hline & $b=13.5469(6)$ & $\mathrm{b}=9.2968(8)$ \\
\hline & $\mathrm{c}=11.6116(6)$ & $\mathrm{c}=18.3506(14)$ \\
\hline & $\alpha=90.00$ & $\alpha=90.00$ \\
\hline & $\beta=90.351(4)$ & $\beta=115.722(10)$ \\
\hline & $\gamma=90.00$ & $\gamma=90.00$ \\
\hline Volume $\left(\AA^{3}\right)$ & $1426.21(11)$ & $1425.6(2)$ \\
\hline$Z$, Calculated density $\left(\mathrm{Mg} / \mathrm{m}^{3}\right)$ & $2,1.366$ & $4,1.559$ \\
\hline Absorption coefficient $\left(\mathrm{mm}^{-1}\right)$ & 0.272 & 8.559 \\
\hline$F(000)$ & 624 & 688 \\
\hline Crystal size $(\mathrm{mm})$ & $0.085 \times 0.093 \times 0.109$ & $0.098 \times 0.091 \times 0.090$ \\
\hline$\theta$ range for data collection $\left(^{\circ}\right)$ & $2.31-25.02$ & $5.35-67.12$ \\
\hline Index ranges & $-10 \leq h \leq 10,-15 \leq k \leq 16,-13 \leq l \leq 13$ & $-10 \leq h \leq 10,-11 \leq k \leq 11,-21 \leq l \leq 21$ \\
\hline Reflections collected/unique & $14204 / 2521\left(\mathrm{R}_{(\mathrm{int})}=0.0271\right)$ & $7666 / 1264\left(\mathrm{R}_{(\mathrm{int})}=0.0406\right)$ \\
\hline Completeness & $100 \%$ to $\theta=25^{\circ}$ & $99.3 \%$ to $\theta=67^{\circ}$ \\
\hline Min. and max. transmission & $0.968-0.984$ & $0.456-0.500$ \\
\hline Refinement method & Full-matrix least-squares on $F^{2}$ & Full-matrix least-squares on $F^{2}$ \\
\hline Data/restraints/parameters & $2521 / 0 / 163$ & $1264 / 0 / 83$ \\
\hline Goodness-of-fit on $F^{2}$ & 1.068 & 1.210 \\
\hline Final $R$ indices $[I>2 \sigma(I)]$ & $R 1=0.0319, w R 2=0.0871$ & $R 1=0.0338, w R 2=0.0875$ \\
\hline$R$ indices (all data) & $R 1=0.0378, w R 2=0.0900$ & $R 1=0.0339, w R 2=0.0877$ \\
\hline Largest diff. peak and hole $\left[\mathrm{e} \AA^{-3}\right]$ & 0.512 and -0.273 & 0.266 and -0.331 \\
\hline
\end{tabular}


were used and reflections inside Ewald sphere were collected up to $\theta=25^{\circ}$ and $\theta=67^{\circ}$, respectively, for 1 and 2. The unit cells parameters were determined from leastsquares refinement of the 1407 and 2709 strongest reflections, respectively, for $\mathbf{1}$ and $\mathbf{2}$. Details concerning crystal data and refinement are given in Table 1. Examination of reflections on two reference frames monitored after each 20 frames measured showed no loss of the intensity during measurements. Lorentz, polarization and numerical absorption [32] corrections were applied. The structures were solved by direct methods. All the non-hydrogen atoms were refined anisotropically using full-matrix, leastsquares technique on $F^{2}$. All the hydrogen atoms were found from difference Fourier synthesis after four cycles of anisotropic refinement, and refined as "riding" on the adjacent atom with individual isotropic displacement factor equal 1.2 times the value of equivalent displacement factor of the patent carbon atoms and 1.5 times of parent oxygen atoms. The carbon bonded hydrogen atom positions were idealised after each cycle of refinement. The SHELXS97, SHELXL97, and SHELXTL [33] software was used for all the calculations. Atomic scattering factors were those incorporated in the computer programs. Selected interatomic bond distances and angles are listed in Table 2, and geometrical parameters of intermolecular interactions are listed in Table 3.

\section{Physical measurements}

IR spectra were recorded on Nicolet Magna 560 spectrophotometer in the spectral range $4000-400 \mathrm{~cm}^{-1}$ with the samples in the form of $\mathrm{KBr}$ pellets. The thermal analyses were carried out in TG-DTA-SETSYS-16/18 thermoanalyser coupled with ThermoStar (Balzers) mass spectrometer. The samples were heated in corundum crucibles up to $1200{ }^{\circ} \mathrm{C}$ at a heating rate $2{ }^{\circ} \mathrm{C} / \mathrm{min}$ in air atmosphere. Dynamic measurements were carried out in air at a flow rate of $1 \mathrm{dm}^{3} \mathrm{~h}^{-1}$. The processes temperature ranges were determined by means of thermoanalyser Data processing module [34]. The solid products of thermal decomposition were determined from derivatographic curves and on the basis of IR spectra and elemental analyses of the sinters. The final and some transition products of decomposition were confirmed by X-ray powder diffraction (XRPD) using the Powder diffraction file [35]. Elemental analyses were carried out using Vario EL III CHNOS Elemental Analyzer $(\mathrm{C}, \mathrm{H}, \mathrm{N}, \mathrm{O}, \mathrm{S})$. The sodium and potassium contents were determined by flame spectrophotometry in mineralised samples. Elemental analyses for studied complex [Calculated/Found (\%)] (1): C 28.66/28.68; H 6.87/6.83; O 21.82/ 21.85; N 23.88/23.86; Na 7.84/7.88; S 10.93/10.94; (2): C 28.72/28.75; H 3.62/3.58; N 25.12/25.13; S 19.17/19.19, K 23.37/23.34.

\section{Results and discussion}

The perspective views of $\mathbf{1}$ and $\mathbf{2}$ are shown in Figs. 1 and 2 , respectively. All atoms of compound $\mathbf{1}$ lie in general positions, but the complex molecule has the internal inversion centre at $0,0.5,0.5$ and thus it occupies two

Table 2 Selected structural data for studied compounds $\left(\AA{ }^{\circ}{ }^{\circ}\right)$

\begin{tabular}{|c|c|c|c|}
\hline \multicolumn{2}{|l|}{1} & \multicolumn{2}{|l|}{2} \\
\hline $\mathrm{Na} 1-\mathrm{O} 4$ & $2.3381(14)$ & $\mathrm{K} 1-\mathrm{N} 11^{\mathrm{ii}}$ & $2.761(2)$ \\
\hline $\mathrm{Na} 1-\mathrm{O} 2$ & $2.3950(14)$ & $\mathrm{K} 1-\mathrm{N} 1$ & $2.9025(19)$ \\
\hline $\mathrm{Na} 1-\mathrm{O} 3$ & $2.4077(15)$ & $\mathrm{K} 1-\mathrm{N} 2^{\mathrm{iii}}$ & $2.9152(19)$ \\
\hline $\mathrm{Na} 1-\mathrm{O} 1^{\mathrm{i}}$ & $2.4270(12)$ & $\mathrm{K} 1-\mathrm{S} 11^{\mathrm{iv}}$ & $3.2990(8)$ \\
\hline $\mathrm{Na} 1-\mathrm{O} 1$ & $2.4887(12)$ & $\mathrm{K} 1-\mathrm{S} 11^{\mathrm{v}}$ & $3.3041(8)$ \\
\hline $\mathrm{Na} 1-\mathrm{N} 1$ & $2.5905(13)$ & $\mathrm{K} 1-\mathrm{S} 11$ & $3.3115(8)$ \\
\hline $\mathrm{S} 51-\mathrm{C} 51$ & $1.619(2)$ & $\mathrm{S} 11-\mathrm{C} 11$ & $1.645(3)$ \\
\hline C51-N51 & $1.155(3)$ & $\mathrm{C} 11-\mathrm{N} 11$ & $1.153(3)$ \\
\hline $\mathrm{O} 4-\mathrm{Na} 1-\mathrm{O} 2$ & $161.35(5)$ & ${ }^{\mathrm{ii}} \mathrm{N} 11-\mathrm{K} 1-\mathrm{N} 1$ & $94.95(7)$ \\
\hline $\mathrm{O} 4-\mathrm{Na} 1-\mathrm{O} 3$ & $91.14(6)$ & ${ }^{\mathrm{ii}} \mathrm{N} 11-\mathrm{K} 1-\mathrm{N} 2^{\mathrm{iii}}$ & $174.76(7)$ \\
\hline $\mathrm{O} 2-\mathrm{Na} 1-\mathrm{O} 3$ & $103.57(5)$ & $\mathrm{N} 1-\mathrm{K} 1-\mathrm{N} 2^{\mathrm{iii}}$ & $90.29(6)$ \\
\hline $\mathrm{O} 4-\mathrm{Na} 1-\mathrm{O} 1^{\mathrm{i}}$ & $83.45(5)$ & ${ }^{\mathrm{ii}} \mathrm{N} 11-\mathrm{K} 1-\mathrm{S} 11^{\mathrm{iv}}$ & $95.93(6)$ \\
\hline $\mathrm{O} 2-\mathrm{Na}-\mathrm{O} 1^{\mathrm{i}}$ & $82.93(4)$ & $\mathrm{N} 1-\mathrm{K} 1-\mathrm{S} 11^{\mathrm{iv}}$ & $91.97(4)$ \\
\hline $\mathrm{O} 3-\mathrm{Na} 1-\mathrm{O} 1^{\mathrm{i}}$ & $99.21(5)$ & ${ }^{\mathrm{iii}} \mathrm{N} 2-\mathrm{K} 1-\mathrm{S} 11^{\mathrm{iv}}$ & $84.02(4)$ \\
\hline $\mathrm{O} 4-\mathrm{Na} 1-\mathrm{O} 1$ & $78.31(5)$ & ${ }^{\mathrm{ii}} \mathrm{N} 11-\mathrm{K} 1-\mathrm{S} 11^{\mathrm{v}}$ & $95.30(6)$ \\
\hline $\mathrm{O} 2-\mathrm{Na} 1-\mathrm{O} 1$ & $88.00(4)$ & $\mathrm{N} 1-\mathrm{K} 1-\mathrm{S} 11^{\mathrm{v}}$ & $91.61(4)$ \\
\hline $\mathrm{O} 3-\mathrm{Na} 1-\mathrm{O} 1$ & $167.86(5)$ & ${ }^{\mathrm{iii}} \mathrm{N} 2-\mathrm{K} 1-\mathrm{S} 11^{\mathrm{v}}$ & $84.37(4)$ \\
\hline $\mathrm{O} 1-\mathrm{Na} 1-\mathrm{O} 1^{\mathrm{i}}$ & $85.68(4)$ & ${ }^{\mathrm{iv}} \mathrm{S} 11-\mathrm{K} 1-\mathrm{S} 11^{\mathrm{v}}$ & $167.86(3)$ \\
\hline $\mathrm{O} 4-\mathrm{Na} 1-\mathrm{N} 1$ & $104.44(5)$ & ${ }^{\mathrm{ii}} \mathrm{N} 11-\mathrm{K} 1-\mathrm{S} 11$ & $77.83(6)$ \\
\hline $\mathrm{O} 2-\mathrm{Na} 1-\mathrm{N} 1$ & $88.20(5)$ & $\mathrm{N} 1-\mathrm{K} 1-\mathrm{S} 11$ & $172.76(4)$ \\
\hline $\mathrm{O} 3-\mathrm{Na} 1-\mathrm{N} 1$ & $85.97(5)$ & ${ }^{\mathrm{iii}} \mathrm{N} 2-\mathrm{K} 1-\mathrm{S} 11$ & $96.93(4)$ \\
\hline $\mathrm{O} 1-\mathrm{Na} 1-\mathrm{N} 1^{\mathrm{i}}$ & $170.56(5)$ & ${ }^{\mathrm{iv}} \mathrm{S} 11-\mathrm{K} 1-\mathrm{S} 11$ & $89.24(2)$ \\
\hline $\mathrm{O} 1-\mathrm{Na} 1-\mathrm{N} 1$ & $90.81(4)$ & ${ }^{\mathrm{v}} \mathrm{S} 11-\mathrm{K} 1-\mathrm{S} 11$ & $88.67(2)$ \\
\hline
\end{tabular}

Symmetry codes: (i) $-x,-y+1,-z+1$; (ii) $x-1 / 2, y-1 / 2, z$; (iii) $x+1 / 2, y+1 / 2, z$; (iv) $-x,-y+1,-z ;(\mathrm{v})-x+1 / 2,-y+1 / 2,-z$

Table 3 Hydrogen bonds in compound $\mathbf{1}\left(\AA,^{\circ}\right)$

\begin{tabular}{lllll}
\hline & $\mathrm{D}-\mathrm{H}$ & $\mathrm{H} \cdots \mathrm{A}$ & $\mathrm{D} \cdots \mathrm{A}$ & $\mathrm{D}-\mathrm{H} \cdots \mathrm{A}$ \\
\hline $\mathrm{O} 1-\mathrm{H} 1 \mathrm{O} \cdots \mathrm{S} 51^{\mathrm{i}}$ & 0.78 & 2.78 & $3.5331(12)$ & 162.7 \\
$\mathrm{O} 1-\mathrm{H} 1 \mathrm{P} \cdots \mathrm{N} 4^{\mathrm{ii}}$ & 0.80 & 2.07 & $2.8706(17)$ & 170.5 \\
$\mathrm{O} 2-\mathrm{H} 2 \mathrm{O} \cdots \mathrm{N} 2^{\mathrm{iii}}$ & 0.77 & 2.06 & $2.8215(17)$ & 167.0 \\
$\mathrm{O} 2-\mathrm{H} 2 \mathrm{P} \cdots \mathrm{N} 51^{\mathrm{iv}}$ & 0.89 & 1.99 & $2.875(3)$ & 175.8 \\
$\mathrm{O} 3-\mathrm{H} 3 \mathrm{O} \cdots \mathrm{S} 51^{\mathrm{v}}$ & 0.72 & 2.80 & $3.4516(15)$ & 151.7 \\
$\mathrm{O} 3-\mathrm{H} 3 \mathrm{P} \cdots \mathrm{N} 51^{\mathrm{vi}}$ & 0.89 & 2.21 & $3.096(3)$ & 171.2 \\
$\mathrm{O}^{\mathrm{i}}-\mathrm{H} 4 \mathrm{O} \cdots \mathrm{N} 3^{\text {vii }}$ & 0.85 & 2.06 & $2.8439(18)$ & 170.9 \\
$\mathrm{O}^{2}-\mathrm{H} 4 \mathrm{P} \cdots \mathrm{O} 2$ & 0.84 & 2.02 & 2.8439 & 171
\end{tabular}

Symmetry codes: (i) $+x,+y,+z$; (ii) $-x+1,-y+1,-z+1$; (iii) $x-0.5,-y+0.5, z+0.5$; (iv) $-x+1,-y+1,-z+1$; (v) $+x-0.5,-y+0.5, z+0.5$; (vi) $-x+0.5, y-0.5,-z+0.5$, (vii) $+x-0.5,-y+0.5, z-0.5$ 
Fig. 1 The molecular conformation of compound $\mathbf{1}$ with atom numbering, plotted with $50 \%$ probability of displacement ellipsoids. The hydrogen atoms are drawn as spheres of arbitrary radii. The symmetry generated atoms (indicated by " $A$ " letter and dashed lines) are obtained by $-x,-y+1,-z+1$ symmetry transformation
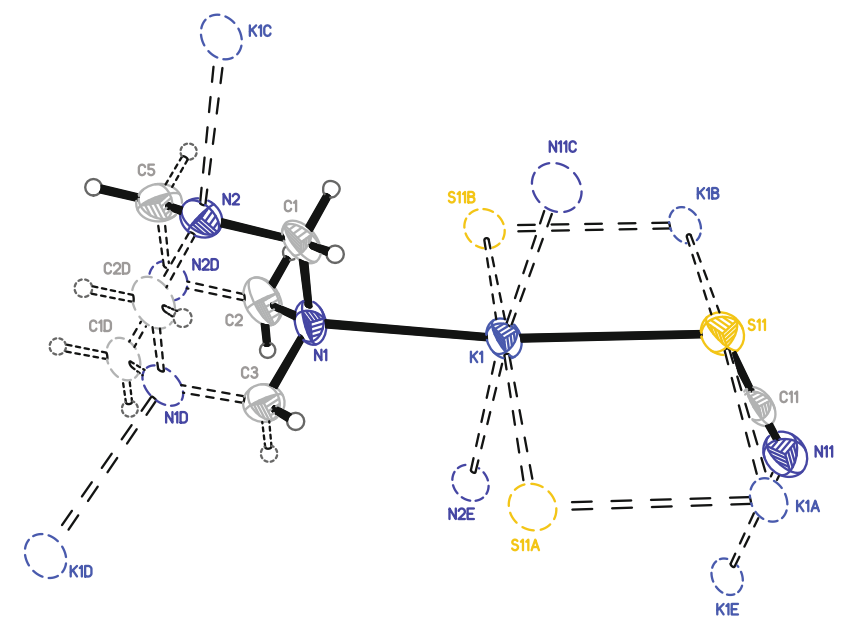

Fig. 2 The molecular conformation of compound 2 with atom numbering, plotted with $50 \%$ probability of displacement ellipsoids. The hydrogen atoms are drawn as spheres of arbitrary radii. The symmetry generated atoms indicated by dashed lines are obtained by symmetry transformations $(A:-x,-y+1,-z ; B:-x+1 / 2,-y+1 / 2$, $-z ; C: x-1 / 2, y-1 / 2, z ; D:-x, y,-z+1 / 2 ; E: x+1 / 2, y+1 / 2, z)$

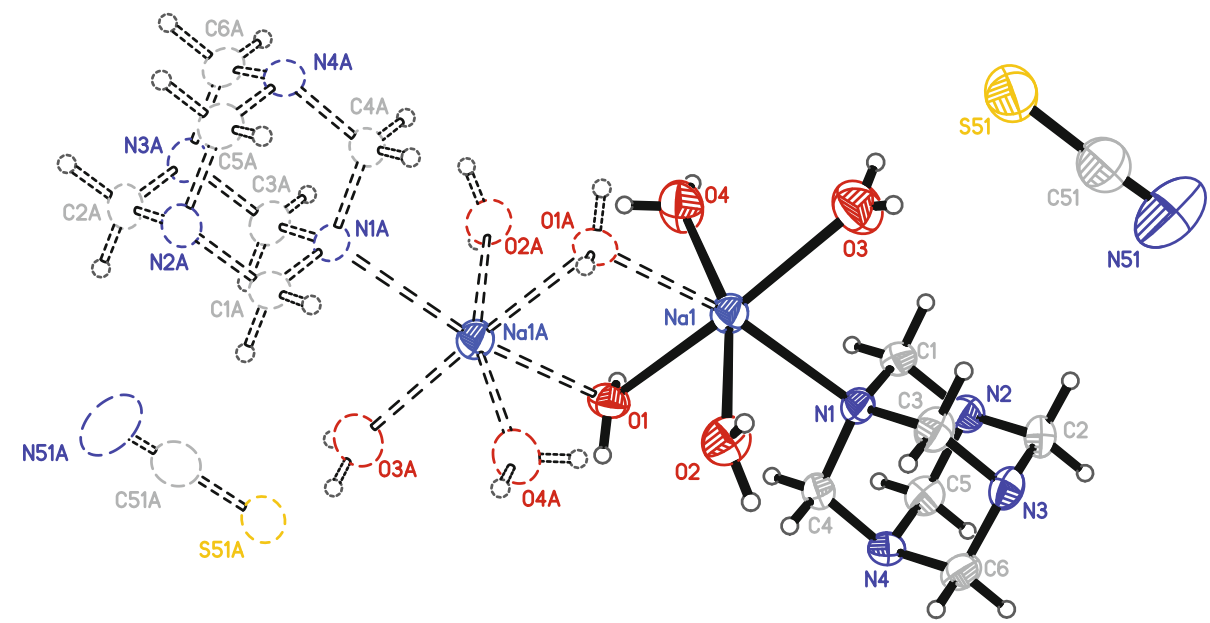

asymmetric units. In compound 2 the $\mathrm{C} 3$ and $\mathrm{C} 5$ atoms of the hmta are located at the special position $e$ of the $C 2 /$ $c$ space group, with site symmetry 2 , therefore, the asymmetric unit contains one potassium cation, one thiocyanate anion and a half of the hmta molecule. This twofold axis together with eight neighbouring symmetry centres expand the asymmetric unit to the three dimensional hybrid compound consisting of two dimensional classical coordination polymer layers extending along crystallographic (001) plane interlined by thiocyanate bridges which forms inorganic layers along (001) plane. The metal centres of 2 create the 12-c uninodal fcu/cubic closest packing net (12/ $3 / \mathrm{c} 1$; sqc19), described by $\left\{3^{24} \cdot 4^{36} \cdot 5^{6}\right\}$ Schläfli symbol and $\left[3^{24} .4(3)^{12} .5(4)^{6}\right]$ simplified extended point symbol. The thiocyanate anions in both compounds show symptoms of disorder what manifests in slightly prolating displacement ellipsoids. Each sodium and potassium cation is six coordinated, the sodium by one monofunctional hmta molecule, three terminal water molecules and two bridging water molecules, and the potassium by two bridging
Fig. 3 The coordination polyhedra of the central atoms. The symmetry generated atoms indicated by dashed lines are obtained by symmetry transformations described in Figs. 1 and 2

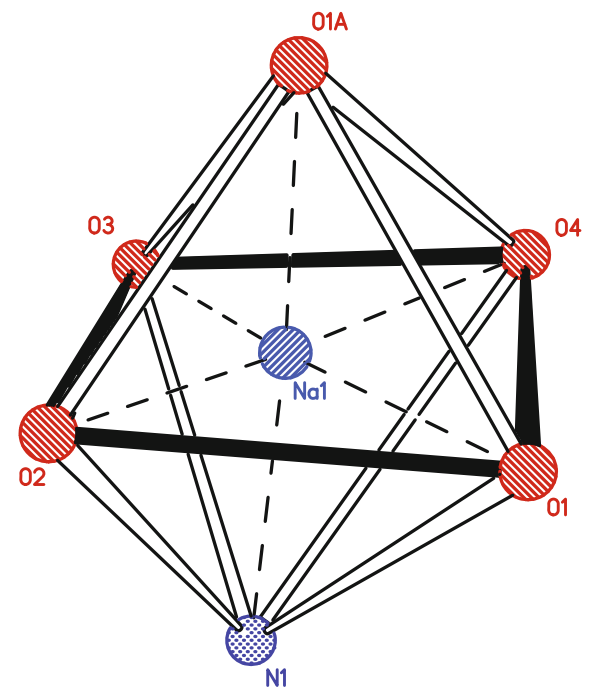

(a)

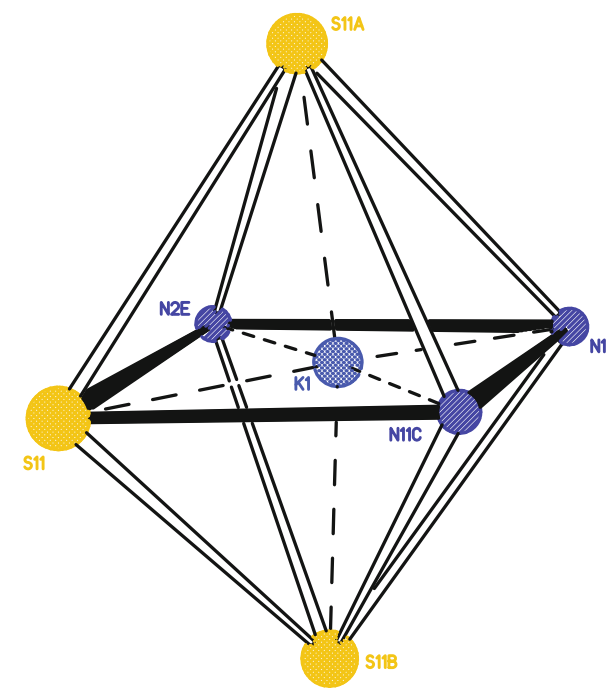

(b) 
Table 4 Vibrational frequencies $\left(\mathrm{cm}^{-1}\right)$ and their assignment in studied compounds

\begin{tabular}{|c|c|c|c|c|c|}
\hline Compound 1 & Compound 2 & $\mathrm{NaSCN}[45]$ & $\mathrm{KSCN}[46]$ & hmta $[47,48]$ & Assignment \\
\hline $3503 \mathrm{bb}$ & & & & & $v_{\mathrm{as}}-(\mathrm{O}-\mathrm{H})$ \\
\hline $3474 \mathrm{bb}$ & & & & & $v_{\mathrm{as}}-(\mathrm{O}-\mathrm{H})$ \\
\hline $3432 \mathrm{bb}$ & & & & & $v_{\mathrm{as}}-(\mathrm{O}-\mathrm{H})$ \\
\hline \multirow[t]{2}{*}{$2960 \mathrm{vw}$} & & & & 2955 & $v_{\mathrm{s}}\left(\mathrm{CH}_{2}\right)$ \\
\hline & $2951 \mathrm{~m}$ & & & 2949 & $v_{\text {as }}\left(\mathrm{CH}_{2}\right)$ \\
\hline \multirow[t]{3}{*}{ 2936vw } & & & & 2946 & $v_{\mathrm{s}}\left(\mathrm{CH}_{2}\right)$ \\
\hline & $2921 w$ & & & 2919 & $v_{\mathrm{s}}\left(\mathrm{CH}_{2}\right)$ \\
\hline & $2903 \mathrm{vw}$ & & & 2909 & $v_{\mathrm{s}}\left(\mathrm{CH}_{2}\right)$ \\
\hline $2887 \mathrm{vw}$ & $2873 w$ & & & 2874 & $v_{\mathrm{s}}\left(\mathrm{CH}_{2}\right)$ \\
\hline $2062 v s$ & $2072 \mathrm{~s}$ & 2075 & 2053 & & $v_{\mathrm{s}}(\mathrm{C} \equiv \mathrm{N})$ \\
\hline $1668 v w$ & & & & & $\delta(\mathrm{O}-\mathrm{H})$ \\
\hline $1497 \mathrm{vw}$ & & & & 1489 & $\sigma\left(\mathrm{CH}_{2}\right)$ \\
\hline $1484 \mathrm{vw}$ & $1486 \mathrm{vw}$ & & & 1485 & $\rho\left(\mathrm{CH}_{2}\right), \rho\left(\mathrm{CH}_{2}\right), \mathrm{CNC}$ deformation \\
\hline \multirow[t]{2}{*}{$1463 \mathrm{~s}$} & $1457 \mathrm{~m}$ & & & 1460 & $\sigma\left(\mathrm{CH}_{2}\right), \mathrm{CH}_{2}$ deformation \\
\hline & $1440 w$ & & & 1441 & CNC deformation, $\sigma\left(\mathrm{CH}_{2}\right)$ \\
\hline $1419 \mathrm{vw}$ & & & & 1435 & CNC deformation \\
\hline $1379 \mathrm{~s}$ & & & & 1394 & $\tau\left(\mathrm{CH}_{2}\right)$ \\
\hline $1334 \mathrm{~m}$ & $1371 \mathrm{~m}$ & & & 1368 & $\omega\left(\mathrm{CH}_{2}\right)$ \\
\hline \multirow[t]{2}{*}{$1317 \mathrm{vw}$} & & & & 1324 & $\tau\left(\mathrm{CH}_{2}\right)$ \\
\hline & $1318 v w$ & & & 1306 & $\omega\left(\mathrm{CH}_{2}\right), \tau\left(\mathrm{CH}_{2}\right)$ \\
\hline $1241 \mathrm{vs}$ & $1236 \mathrm{~s}$ & & & 1240 & $\rho\left(\mathrm{CH}_{2}\right), v(\mathrm{C}-\mathrm{N})$ \\
\hline \multirow[t]{3}{*}{$1201 \mathrm{vw}$} & & & & 1192 & $\omega\left(\mathrm{CH}_{2}\right)$ \\
\hline & $1132 \mathrm{vw}$ & & & 1129 & CNC deformation \\
\hline & 1048w & & & 1048 & $\tau\left(\mathrm{CH}_{2}\right), \mathrm{CNC}$ deformation, $\delta(\mathrm{NCN})$ \\
\hline $1008 v s$ & 1006vs & & & 1007 & $v(\mathrm{C}-\mathrm{N})$ \\
\hline $934 \mathrm{vw}$ & $931 \mathrm{vw}$ & & & 925 & $v(\mathrm{C}-\mathrm{N}), \rho\left(\mathrm{CH}_{2}\right)$ \\
\hline $813 \mathrm{~m}$ & $811 \mathrm{~m}$ & & & 812 & $v(\mathrm{C}-\mathrm{N}), \rho\left(\mathrm{CH}_{2}\right)$ \\
\hline 760bb & & & & 777 & $v(\mathrm{C}-\mathrm{N}), \rho\left(\mathrm{CH}_{2}\right)$ \\
\hline $749 w$ & $734 w$ & 755 & 749 & & $v_{\mathrm{s}}(\mathrm{C}-\mathrm{S})$ \\
\hline $688 \mathrm{~s}$ & $673 w$ & & & 673 & $\delta(\mathrm{N}-\mathrm{C}-\mathrm{N}), \mathrm{CNC}$ deformation \\
\hline $661 \mathrm{vw}$ & & & & 659 & $\delta(\mathrm{N}-\mathrm{C}-\mathrm{N})$ \\
\hline $404 \mathrm{vs}$ & 410 & 497 & 470 & & $v-\beta(\mathrm{SCN})$ deformation \\
\hline
\end{tabular}

Used symbols: $v w$ very weak, $w$ weak, $m$ medium strength, $s$ strong, $v s$ very strong, $v$ stretching, $\delta$ bending, $\rho$ rocking, $\sigma$ scissoring, $\tau$ waging, $\omega$ twisting, $\beta$ in plane, $s$ symmetric, $a s$ asymmetric, $b b$ broad band

tetrafunctional hmta molecules and four bridging tetrafunctional thiocyanate ions. The bridging water molecules of $\mathbf{1}$ are asymmetrically bonded to the metal ions (Table 2). The coordination polyhedra of the central atoms can be described as distorted tetragonal bipyramids (Fig. 3). The maximum deviation from $04 / \mathrm{O} 2 / \mathrm{O} 1 / \mathrm{O} 3$ plane of $0.1933(7) \AA$ exists for $\mathrm{O} 4$ atom, from $\mathrm{O} 4 / \mathrm{O} 2 / \mathrm{O} 1{ }^{\mathrm{i}} / \mathrm{N} 1$ plane of $0.1010(7) \AA$ exists for $\mathrm{O}^{\mathrm{i}}$ atom and from $\mathrm{O} 1 / \mathrm{O} 3 / \mathrm{O} 1^{\mathrm{i}}$ / N1 plane of $0.2177(8) \AA$ exists for $\mathrm{O} 1$ atom (hereafter symmetry codes as in Table 2). The sodium atom derives $0.0719(8), 0.1817(9)$ and 0.0307(8) $\AA$ from above planes, respectively. The maximum deviations from polyhedron $\mathrm{N} 1 / \mathrm{S} 11 / \mathrm{N} 11^{\mathrm{ii}} / \mathrm{N} 2^{\mathrm{iii}}, \mathrm{N} 11^{\mathrm{ii}} / \mathrm{N} 2^{\mathrm{iii}} / \mathrm{S} 11^{\mathrm{iv}} / \mathrm{S} 11^{\mathrm{v}}$ and $\mathrm{S} 11^{\mathrm{iv}} / \mathrm{S} 11^{\mathrm{v}} /$ $\mathrm{N} 1 \mathrm{~S} 11$ planes exist for $\mathrm{N} 11^{\mathrm{ii}}, \mathrm{N} 2^{\mathrm{iii}}$ and $\mathrm{N} 1$ atoms, and they are equal to $0.0046(11), 0.0073(9)$ and $0.2778(7) \AA$, respectively. The potassium atom derives 0.0076(11), $0.1229(10)$ and $0.2561(7) \AA$ from above planes, respectively. The planes create dihedral angles of 84.73(3), $89.01(3)$ and $86.38(3)^{\circ}$, respectively for pairs $\mathrm{O} 4 / \mathrm{O} 2 / \mathrm{O} 1 /$ $\mathrm{O} 3-\mathrm{O} 4 / \mathrm{O} 2 / \mathrm{O} 1^{\mathrm{i}} / \mathrm{N} 1, \mathrm{O} 4 / \mathrm{O} 2 / \mathrm{O} 1^{\mathrm{i}} / \mathrm{N} 1-\mathrm{O} 1 / \mathrm{O} 3 / \mathrm{O} 1^{\mathrm{i}} / \mathrm{N} 1$ and $\mathrm{O} 1 /$ $\mathrm{O} 3 / \mathrm{O} 1^{\mathrm{i}} / \mathrm{N} 1-\mathrm{O} 4 / \mathrm{O} 2 / \mathrm{O} 1 / \mathrm{O} 3$ of compound 1 and $89.95(3)$, $83.68(2)$ and $89.75(3)^{\circ}$ for pairs N1/S11/N1 $1^{\mathrm{ii}} / \mathrm{N} 2^{\mathrm{iii}}-\mathrm{N} 11^{\mathrm{ii} /}$ $\mathrm{N} 2^{\mathrm{iii}} / \mathrm{S} 11^{\mathrm{iv}} / \mathrm{S} 11^{\mathrm{v}}$ and $\mathrm{N} 11^{\mathrm{ii}} / \mathrm{N} 2^{\mathrm{iii}} / \mathrm{S} 11^{\mathrm{iv}} / \mathrm{S} 11^{\mathrm{v}}-\mathrm{S} 11^{\mathrm{iv}} / \mathrm{S} 11^{\mathrm{v}} /$ $\mathrm{N} 1 \mathrm{~S} 11$ and $\mathrm{S} 11^{\mathrm{iv}} / \mathrm{S} 11^{\mathrm{v}} / \mathrm{N} 1 \mathrm{~S} 11-\mathrm{N} 1 / \mathrm{S} 11 / \mathrm{N} 11^{\mathrm{ii}} / \mathrm{N} 2^{\mathrm{iii}}$ of compound 2.

The bond valences were computed as $v_{i j}=\exp \left[\left(R_{i j}-\right.\right.$ $\left.d_{i j}\right) / b$ ] [36, 37], where $R_{i j}$ is the bond-valence parameter (in the formal sense $R_{i j}$ can be considered as a parameter equal 


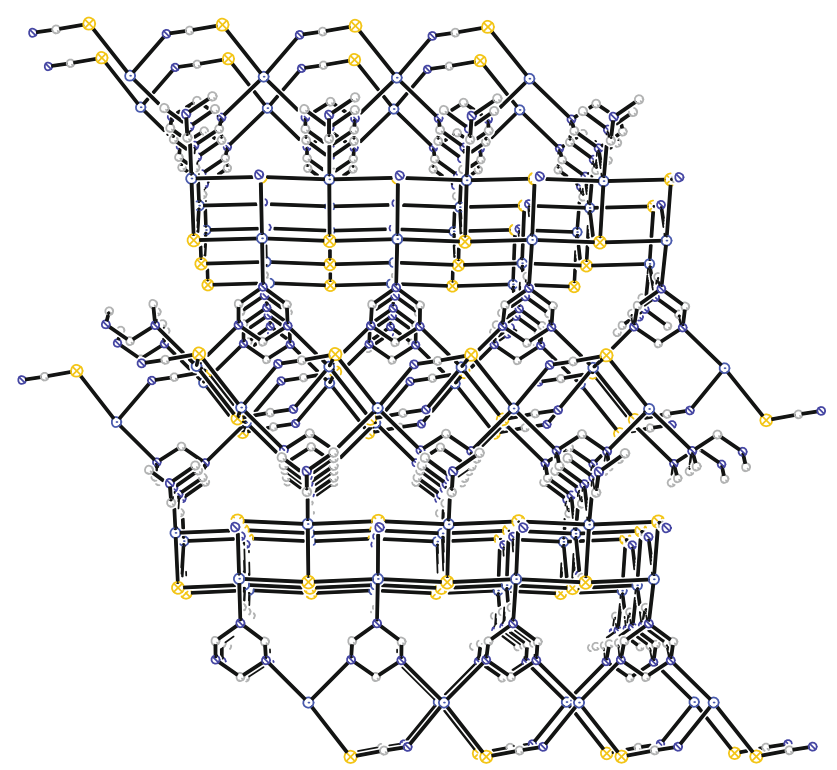

Fig. 4 A part of molecular packing of compound 2 showing the three dimensional hybrid net. The hydrogen atoms are omitted for clarity
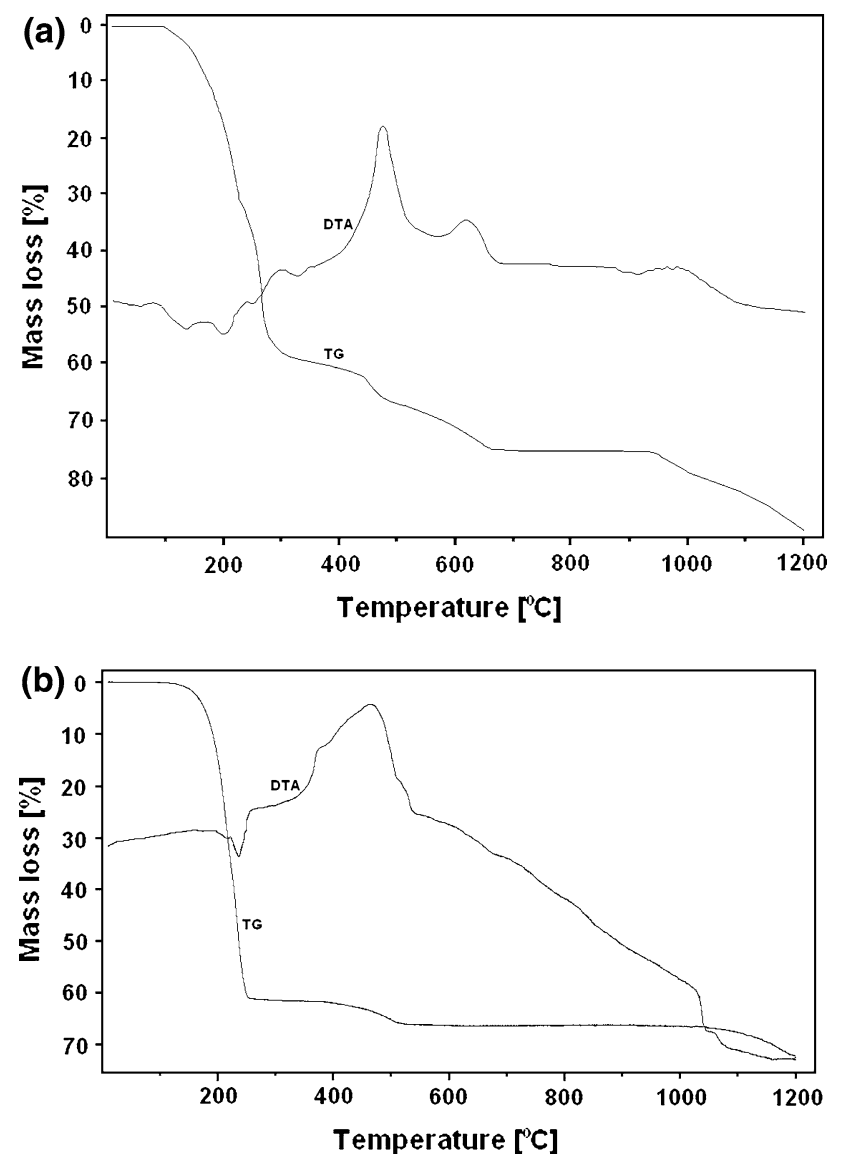

Fig. 5 The TG and DTA curves of compound 1 (a) and 2 (b) to the idealised single-bond length between $i$ and $j$ atoms for given $b$ ) and $b$ was taken as $0.37 \AA$ [38-41]. The $R_{\mathrm{Na}-\mathrm{O}}$, $R_{\mathrm{Na}-\mathrm{N}}, R_{\mathrm{K}-\mathrm{N}}$ and $R_{\mathrm{K}-\mathrm{S}}$ were taken as $1.80,1.93,2.26$ and 2.59 , respectively [42]. The computed bond valences of the metal ions are $v_{\mathrm{Na} 1-\mathrm{O} 1}=0.155, v_{\mathrm{Na} 1-\mathrm{O} 2}=0.200, v_{\mathrm{Na} 1-\mathrm{O} 3}=$ $0.194, v_{\mathrm{Na} 1-\mathrm{O} 4}=0.234, v_{\mathrm{Na} 1-\mathrm{O} 1 \mathrm{i}}=0.184, v_{\mathrm{Na} 1-\mathrm{N} 1}=0.186$, $v_{\mathrm{K} 1-\mathrm{N} 11 \mathrm{ii}}=0.258, v_{\mathrm{K} 1-\mathrm{N} 1}=0.176, v_{\mathrm{K} 1-\mathrm{N} 2 \mathrm{iii}}=0.170, v_{\mathrm{K} 1-\mathrm{S} 11 \mathrm{iv}}=$ $0.147, v_{\mathrm{K} 1-\mathrm{S} 11 \mathrm{v}}=0.145, v_{\mathrm{K} 1-\mathrm{S} 11}=0.142 \mathrm{v} . \mathrm{u}$. (valence units) thus the computed valence of the $\mathrm{Na} 1$ atom is $1.134 \mathrm{v} . \mathrm{u}$ and the $\mathrm{K} 1$ atom is 1.039 . The small deviation of valence sum rule can be explained by constraints imposed by formation of the stiff $\mathrm{Na}_{2} \mathrm{O}_{2}$ ring in $\mathbf{1}$ and creation of a relatively rigid polymer net in $\mathbf{2}$ (Fig. 4). In 1 the weakest is the one of $\mathrm{Na}-\mathrm{O}$ bridging bonds and the $\mathrm{Na}-\mathrm{N}$ bond. The bonds linking the cation and terminal water molecules have different strength what originates from different strength of hydrogen bonds created by these water molecules (stronger hydrogen bonds lead to weaker $\mathrm{Na}-\mathrm{OH}_{2}$ bonds and vice versa). In case of 2 the strongest is one $\mathrm{K}-\mathrm{N}$ (thiocyanate) bond, the $\mathrm{K}-\mathrm{N}(\mathrm{hmta})$ bonds are the mildly strong ones, and the weakest are $\mathrm{K}-\mathrm{S}$ bonds. In the structure of compound $\mathbf{1}$ the multiple intramolecular $\mathrm{O}$ (water) - $\mathrm{H} \cdots \mathrm{N}(\mathrm{hmta} / \mathrm{NCS})$ and $\mathrm{O}$ (water)H...S hydrogen bonds [43, 44] exist (Table 3; Fig. 3) and they create the three dimensional net. In addition, each complex molecule of $\mathbf{1}$ is stabilised by intramolecular $\mathrm{O}-\mathrm{H} \cdots \mathrm{O}$ hydrogen bonds linking two terminal water molecules bonded to two different cations. In compound $\mathbf{2}$ any short contacts which can be classified as hydrogen bonds cannot be found.

In the IR spectra of both studied compounds a very strong, characteristic peak originating from thiocyanate $\mathrm{C} \equiv \mathrm{N}$ bond stretching symmetric vibration is observed at about $2070 \mathrm{~cm}^{-1}$ and in the case of $\mathbf{1}$ it is shifted to lower (about $13 \mathrm{~cm}^{-1}$ ) frequencies and in 2 to higher (about $19 \mathrm{~cm}^{-1}$ ) frequencies in comparison to respect pure salts (sodium [45] and potassium [46] thiocyanate, Table 4). In 1 this is caused by outer coordination sphere placement of $\mathrm{SCN}^{-}$ion and its binding by $\mathrm{O}-\mathrm{H} \cdots \mathrm{N}_{\text {(thiocyanate) }}$ and $\mathrm{O}-\mathrm{H} \cdots \mathrm{S}$ hydrogen bonds (these intermolecular interactions weaken the internal anion oscillators strength due to formation of multidirectional intermolecular bonding). In compound $\mathbf{2}$ the shift is caused by the creation of the rigid net in which the thiocyanate nitrogen atom creates the bond with the potassium cation. The similar weakening of the $\mathrm{C}-\mathrm{S}$ symmetric stretching vibrations at about $750 \mathrm{~cm}^{-1}$ is observed in both compounds. In $\mathbf{1}$ it is caused by the above described intermolecular interactions and in $\mathbf{2}$ it originates from surrounding of each sulphur atom by three potassium cations in meridional arrangement and placement of the thiocyanate carbon atom in semifacial arrangement to the pairs of cations (over the half of electrons sphere around the sulphur atom does not create any bonds). In presented coordination compounds the band originating from stretching in plane vibration of $\mathrm{SCN}^{-}$ion is shifted to 
Scheme 1 Stages of the thermal decomposition of studied compounds (m.l. experimental mass loss/ theoretical mass loss, v.p. volatile products, * product was confirmed by XRPD)

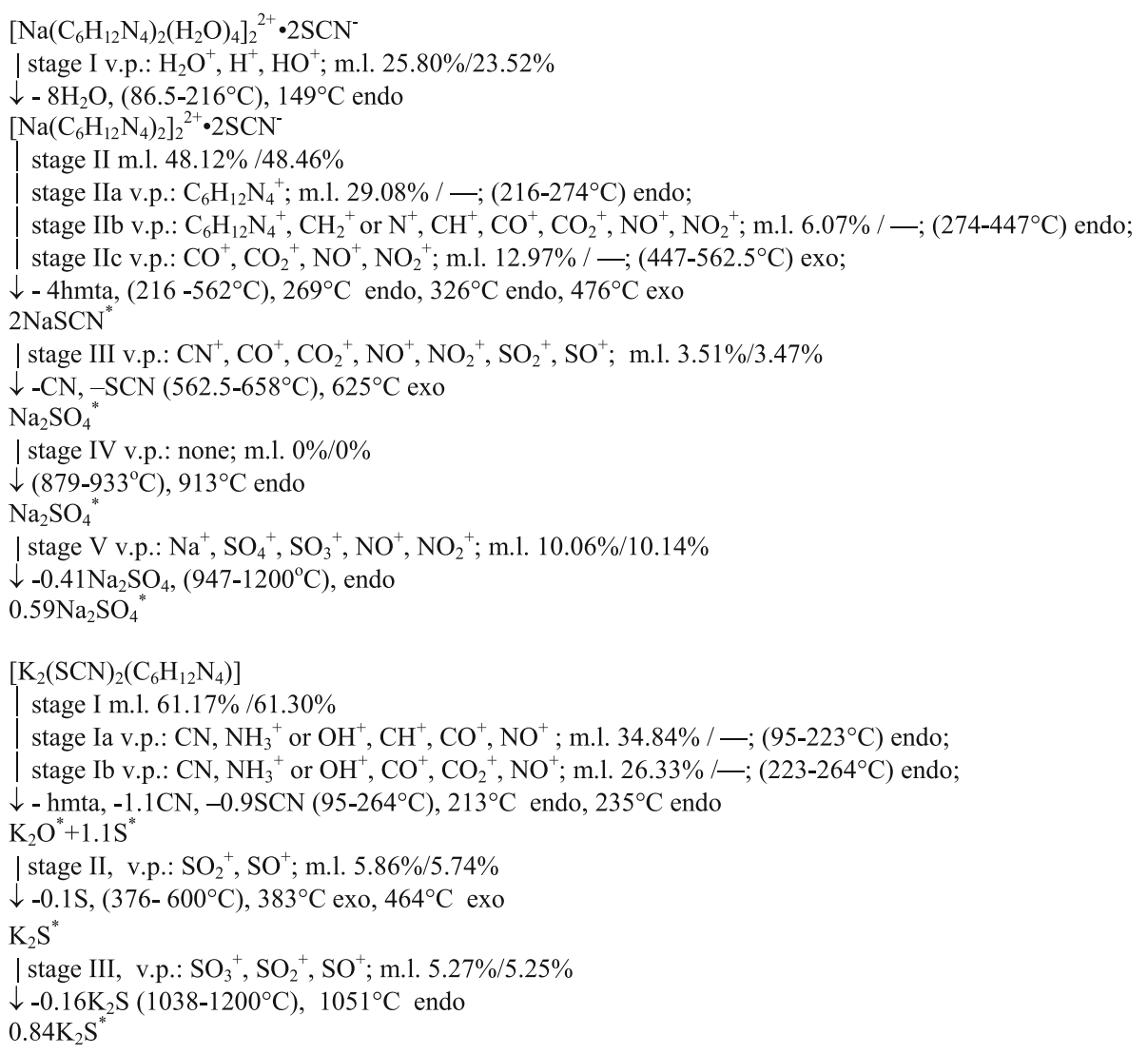

lower frequencies in comparison to pure salts [45, 46] (Table 4). It is caused by the strong ionic bonds in inorganic salts leading to the large oscillators energy, lesser restraints created by bonds of hybrid 2 and the interaction of the anion of $\mathbf{1}$ with neighbouring species only by hydrogen bonds (the smallest energy is required for functioning of the oscillator). The most complex absorption bands present in the IR spectra are caused by vibrations of hmta atoms (Table 4) [47, 48]. The differences in hydrogen bonding scheme between the pure hmta and $\mathbf{1}$ leads to weakening of the principal $\mathrm{C}-\mathrm{N}$ oscillator of $\mathbf{1}$ at about $770 \mathrm{~cm}^{-1}$ and broadening of the observed band. The creation of coordination bonds between hmta molecules and metal cations leads to increase of the $v(\mathrm{C}-\mathrm{N})$ oscillator strength (at $934 \mathrm{~cm}^{-1}$ ) in comparison to the pure ligand (Table 4).

The thermal decomposition of studied compounds is a gradual process (Fig. 5). According to TG and DTG curves, analyzed compounds decompose in four (five including melting without mass loss) and three steps, respectively, for $\mathbf{1}$ and $\mathbf{2}$ (Scheme 1). The hydrated $\mathbf{1}$ losses all eight water molecules in the first step. Next the anhydrous complex begins to decompose and in the first substage (clearly exhibited on the DTG and DTA curves) the hmta molecules are released, in the second substage hmta molecules simultaneously sublimate and oxidate to volatile products and in the final, third, substage only the gaseous products of oxidation are formed. After whole amine releasing, the anhydrous sodium thiocyanate starts to transfer to sodium sulphate(VI) and this change finishes at about $660{ }^{\circ} \mathrm{C}$. The further heating leads to melting sodium sulphate(VI) and next to its evaporation. At the end of the process about 0.6 of the initial amount of sodium sulphate(VI) remains and it evaporates completely after 75 min of heating at the $1200{ }^{\circ} \mathrm{C}$.

The anhydrous $\mathbf{2}$ is distinctly more thermally unstable than 1 (the decomposition of water-free 1 begins at temperature of about $120{ }^{\circ} \mathrm{C}$ higher than the anhydrous 2) and the thermal decomposition stages are extremely different. In the first step of the thermal decomposition of $\mathbf{2}$ the hmta molecules and the thiocyanate ions decompose in the one rapid process composed from the two substages according to the DTG and DTA curves. Next, the formed potassium oxide reacts (at its decomposition temperature) with melted elemental sulphur. This process is accompanied by boiling of sulphur and evaporation of its unreacted (with metal) excess in form of sulphur oxides. The formed potassium sulphide is stable to about $1040{ }^{\circ} \mathrm{C}$ and further heating leads to its slow decomposition. At the end of the process about 0.85 of the initial amount of potassium sulphide remains and it evaporates completely after $64 \mathrm{~min}$ of heating at the $1200{ }^{\circ} \mathrm{C}$. During the heating of the formed 
$\mathrm{K}_{2} \mathrm{~S}$, the surface oxidation of the melt probably occurs (due to contact of the melt with the air) with possible formation of sulphates from sulphide, however, the potassium sulphates are not observed on the XRPD patterns of the sinters, probably due to very small amounts of created potassium sulphates.

\section{Conclusion}

The reaction of hmta with sodium and potassium thiocyanate leads to the formation of coordination complex compounds. The one of the two used, potentially multifunctional, ligands-the hmta-acts in monofunctional mode in $\mathbf{1}$ and in tetrafunctional mode in $\mathbf{2}$, and the second one exists in the outer coordination sphere in $\mathbf{1}$ and exhibits tetrafunctional mode in $\mathbf{2}$. The dinuclear core of the complex ion of $\mathbf{1}$ is created by two sodium cations and two water molecules. Noteworthy is the fact that, on the basis of Lewis theory in Pearson's extension, it can be assumed that the thiocyanate ligand should coordinate to a hard metal cation (such as $\mathrm{Na}^{+}$) via $\mathrm{S}$ end instead of coordination via $\mathrm{N}$ end or instead of hmta as it is observed in the case of compound 2. The S thiocyanate end should primarily compete with water molecules in creation of the inner coordination sphere and next the unoccupied inner coordination sphere voids should be occupied by $\mathrm{S}$ thiocyanate ends or $\mathrm{N}$-donor hmta molecules. The energetically favoured (in case of compound 1) existence of hmta boned to the sodium cation in occurrence of the outer coordination sphere located thiocyanate anion is a relatively uncommon example of extended Lewis theory violation. The same reaction of hmta with potassium thiocyanate gives coordination polymer fulfilling the Lewis theory postulates. Noteworthy is the uncommon fact, that formation of hybrid net in $\mathbf{2}$ decreases the thermal stability in comparison to hydrogen bonded supramolecular assembly existing in $\mathbf{1}$.

Acknowledgments This study was financed by funds allocated by the Ministry of Science and Higher Education to the Institute of General and Ecological Chemistry, Technical University of Lodz.

Open Access This article is distributed under the terms of the Creative Commons Attribution Noncommercial License which permits any noncommercial use, distribution, and reproduction in any medium, provided the original author(s) and source are credited.

\section{References}

1. Xu RB, Xu XY, Li SA, Wang MY, Yang XJ, Wang DQ, Huang YP, Xu CM (2010) Struct Chem 21:1085
2. He R, Liang Q, Song HH, Wei Z (2010) Struct Chem 21:923

3. Zhan CH, Feng YL (2010) Struct Chem 21:893

4. Wang Y, Şerb M, Englert U (2010) Struct Chem 21:203

5. Kaczmarek MT, Kubicki M, Radecka-Paryzek W (2010) Struct Chem 21:779

6. Liu FC, Zeng YF, Li JR, Bu XH, Zhang HJ, Ribas J (2005) Inorg Chem 44:7298

7. Bai Y, Shang WL, Dang DB, Sun JD, Gao H (2009) Spectrochim Acta Part A 72:407

8. Wang J, Djukic B, Cao J, Alberola A, Razavi FS, Pilkington M (2007) Inorg Chem 46:8560

9. Dohyun M, Sangmi K, Jaejoon P, Myoung SL (2006) J Am Chem Soc 128:3530

10. Zhang J, Hubert-Pfalzgraf LG, Luneau D (2004) Inor Chem Commun 7:979

11. Atencio R, Briceno A, Silva P, Rodriguez JA, Hanson JC (2007) New J Chem 31:33

12. Winter S, Weber E, Eriksson L, Csoregh I (2006) New J Chem 30:1808

13. Janiak C (2003) Dalton Trans p 2781

14. Zou HH, Zhang SH, Xiao Y, Feng C, Wang YG (2011) Struct Chem 22:135-140

15. Shi JM, Sun YM, Liu LD, Shi W, Cheng P (2006) Dalton Trans p 376

16. Eddaoudi M, Moler DB, Li H, Chen B, Reineke TM, O'Keeffe M, Yaghi OM (2001) Acc Chem Res 34:319

17. Evans OR, Lin W (2002) Acc Chem Res 35:511

18. Seo JS, Whang D, Lee H, Jun SI, Oh J, Jeon YJ, Kim K (2000) Nature 404:982

19. Wan WG, Chen CN, Liu QT (2005) Chinese J Struct Chem 24:821

20. Lu JY, Macias J, Lu J, Cmaidalka JE (2002) Cryst Growth Des 2:485

21. Galan-Mascaros JR, Dunbar KR (2003) Angew Chem Int Ed 42:2289

22. Trzesowska-Kruszynska A, Kruszynski R, Zalewicz M, Bartczak TJ (2010) J Coord Chem 63:1013

23. Looney MG, Solomon DH (1995) Aust J Chem 48:323

24. Chakraborty J, Samanta B, Batsanov AS, Ribas J, Salah El Fallah M, Mitra S (2006) Struct Chem 17:401

25. Liu Q, Li YZ, Liu HJ, Wang F, Xu Z (2005) J Mol Struct 733:25

26. Banerjee S, Choudhury AR, Drew MGB, Row TNG, Chaudhuri S, Ghosh A (2007) Polyhedron 26:24

27. Ghosh AK, Ghoshal D, Drew MGB, Mostafa G, Chaudhuri RN (2006) Struct Chem 17:85

28. Wang RH, Yuan DQ, Jiang FL, Han L, Gong YQ, Hong MC (2006) Cryst Growth Des 6:1351

29. Małecki JG, Machura B, Świtlicka A (2011) Struct Chem 22:77

30. Li YT, Liu ZQ, Wu ZY, Jiang M, Li XW (2008) Struct Chem 19:819

31. Zhu H, Ströbele M, Yu Z, Wan Z, Meyer HJ, You X (2001) Inorg Chem Commun 4:577

32. X-RED Version 118 STOE \& Cie GmbH Darmstadt Germany (1999)

33. Sheldrick GM (2008) Acta Crystallogr Sect A 64:112

34. Data Processing Module Copyright (C) 1994-1998 SETARAMFRANCE, Version 14

35. Powder Diffraction File International Center of Diffraction Data, 12 Campus Boulevard, Newton Square (2003)

36. Zachariasen WH (1978) J Less Common Metals 62:1

37. Brown ID (1997) Acta Cryst Sect B 53:381

38. Brown ID (1992) Acta Cryst Sect B 48:553

39. Trzesowska A, Kruszynski R, Bartczak TJ (2004) Acta Crystallogr Sect B 60:174

40. Trzesowska A, Kruszynski R, Bartczak TJ (2005) Acta Crystallogr Sect B 61:429 
41. Trzesowska A, Kruszynski R, Bartczak TJ (2006) Acta Crystallogr Sect B 62:745

42. Brese NE, O'Keeffe M (1991) Acta Cryst Sect B 47:192

43. Taylor R, Kennard O (1982) J Am Chem Soc 104:5063

44. Desiraju GR, Steiner T (1999) The weak hydrogen bond in structural chemistry and biology. Oxford University Press, Oxford
45. Bortnuchik AL, Stepukhovich AD, Rabinovuch IS (1973) Zhurnal Prikladnoi Spektroskopii 19:127

46. Jones LH (1958) J Chem Phys 28:1234

47. Bernstein MP, Sandford SA, Allamandola LJ, Chang S (1994) J Phys Chem 98:12206

48. Jensen JO (2002) Spectrochimica Acta Part A 58:1347 